\title{
Put Yourself in My Shoes
}

\section{Raymond Carver}

The telephone rang while he was running the vacuum cleaner. By this time he had worked his way through the apartment and was on the living room. He was using the brush attachment on the hose in order to get at cat hairs between the cushions. He could faintly hear the ringing. He stopped and listened, and then switched off the vacuum. He went to answer the telephone.

"Hello," he said. "Myers here."

"Myers, honey," she said. "How are you? What are you doing?"

"Nothing," he said. "Hello, Paula."

"There's an office party this afternoon," she said. "You're invited. Carl invited you."

"I don't think I can come," Myers said.

"Carl just this minute said get that old man of yours on the phone. Get him down here for a drink. Get him out of his ivory tower and back into the real world for a while. He's funny when he's drinking. Myers?"

"I heard you," Myers said. Myers used to work for Carl. Carl always talked of going to Paris and writing a novel. He had been sorry to see Myers quit. But Carl said he would watch for his name on the best-seller list. "I can't come now," Myers said.

"We found out some horrible news this morning," she continued, as if she hadn't heard him. "You remember Larry Gudinas. He was still here when you came to work. He helped out on science books for a while, and then they put him in the field, and then they canned him? We heard this morning he committed suicide. He shot himself in the mouth. Can you imagine? He lingered for three days, poor man. Think how his family must feel. Myers?"

"I heard you," Myers said. He tried to remember Larry Gudinas and recalled a tall, stooped man with wire frame glasses, bright ties, and a receding hairline. He could imagine the jolt, the head snapping back as the bullet tore into the open mouth. "Jesus," he said. "Well, I'm sorry to hear that."

"Come down to the office, honey, all right?" Paula said. "Everybody is just 
talking and having some drinks and listening to Christmas music. Come down," she said again.

He could hear the clink of glasses, loud voices, and then laughter at the other end of the line. "I don't want to come down," he said. "Paula?" A few snowflakes drifted past the window as he watched. He rubbed his finger across the glass, and then began to write his name on the glass as he waited.

"What? I heard," she said. "All right," she said. "Well, then, why don't we meet at Voyles for a drink? Myers?"

"Okay," he said. "Voyles, all right."

"Everybody here will be disappointed you didn't come," she said. "Carl especially. He admires you, you know. He does. He's told me so. He admires your nerve. He said if he had your nerve he would have quit years ago. It takes nerve to do what you did, he says. Myers?"

"I'm right here," Myers said. "I think I can get my car started. If I can't start it, I'll call you back."

"All right," she said. "I'll see you at Voyles. I'll leave here in a few minutes."

"Say hello to Carl for me," Myers said.

"I will," she said. "He's always talking about you."

He put the vacuum cleaner away. He shaved, put on another shirt, his shoes, and found his coat. He walked down the two flights and went to his car which was in the last stall and covered with snow. He got in, worked the pedal a number of times, and tried the starter. It turned over, roared. He continued to press the pedal.

As he drove he looked at the people who hurried along the walks with shopping bags. He glanced at the gray sky, filled with flakes, and at the tall buildings with snow in the crevices and on the window ledges. He tried to see everything, save it for later. He was between stories, and he felt despicable. He found Voyles, a small bar on a corner next to a men's clothing store. He parked in back and went inside. He sat at the bar for a time and then carried a drink over to a little table near the door.

Paula came in then and said, "Merry Christmas, honey," and he got up and gave her a kiss on the cheek. He held a chair for her.

"What'll you have?" he said. "Scotch?"

"Scotch," she said. Then, "Scotch over ice," to the girl who came for her order.

Paula picked up his drink and drained the glass.

"I'll have another one too," Myers said to the girl. "I don't like this place," he said after the girl had moved away.

"What's wrong with it?" Paula said. "We used to come here. It's quiet, the drinks are good."

"I just don't like it," he said. "Let's have a drink and then go someplace else."

"Whatever you want," she said.

The girl arrived with the drinks, Myers paid her, and he and Paula touched glasses.

Paula's eyelids drooped slightly and her lips seemed puffed as she smiled. Myers 
stared. She could hold her drinks, but once in a while, if she had too much, she passed out.

"Carl says hello."

Myers nodded.

She sipped her drink. "How was your day today?"

He shrugged.

"What'd you do?" she said.

"Nothing," he said. "I vacuumed."

She touched his hand. "Everybody said to tell you hi."

They finished their drinks. "I have an idea," she said. "Why don't we stop and visit the Morgans for a few minutes? We've never met them, for God's sake. They've been back for months. We could just drop by and say 'Hello, we're the Myers.' Besides, they sent us a card. They asked us to stop during the holidays. They invited us. I don't want to go home," she added and fished in her purse for a cigarette.

Myers recalled setting the furnace and turning out all the lights that afternoon before he left for Voyles. He recalled the snow drifting past the window. "What about that insulting letter they sent telling us they heard we were keeping a cat in the house?" he said.

"They've forgotten about that by now," she said. "That wasn't anything serious anyway. Oh, let's do it, Myers! Let's go by."

"We should call first, if we're going to do anything like that," he said.

"No," she said. "That's part of it. Let's not call. Let's just go knock on the door and say 'Hello, we used to live here.' All right? Myers?"

"I think we should call," he said.

"It's the holidays," she said, getting up from her chair. "Come on, honey." She took his arm and they went outside.

He suggested they take her car and pick his car up later. Snow was falling. Most of the stores had closed. There were only a few people on the street. He opened the car door for her and then went around to the driver's side.

He pulled up in front of the house where they had lived for a year and turned the key off. Something took him as he saw the lighted windows, snow on the roof, and the station wagon in the drive. The curtains were open and Christmas tree lights blinked at them from behind the window.

They got out of the car. He took her elbow as they stepped over a pile of snow and started up the walk to the front porch. They had gone a few steps when a large bushy dog hurtled around the corner of the garage and headed straight for Myers.

"Oh, God," he said, hunching, stepping back and bringing his hands up. He slipped on the walk, his coat flapped, and he fell onto the frozen grass with the dread certainty that the dog would go for his throat. The dog growled once and then began to sniff Myers' coat.

Paula picked up a handful of snow and threw it at the dog. The porchlight came on, the door opened, and a man called, "Buzzy!" Myers got to his feet and began to brush himself off. 
"What's going on?" the man in the doorway said. "Who is it? Buzzy, come here fellow. Come here."

"We're the Myers," Paula said with a nervous laugh. "We came to wish you a merry Christmas."

"The Myers?" the man in the doorway said, as if puzzled. "Get out! Get in the garage, Buzzy. Get, get! It's the Myers," he said to the woman who stood behind him trying to look past his shoulder.

"The Myers," she said. "Well, ask them in, ask them in, for heaven's sake." She stepped onto the porch and said, "Come in, please, it's freezing. I'm Hilda Morgan and this is Edgar. We're happy to meet you. Please come in."

They shook hands quickly on the front porch. Myers and Paula stepped inside and Edgar shut the door.

"Let me have your coats. Take off your coats," Edgar said. "You're all right?" he said to Myers, observing him closely, and Myers nodded. "I knew that dog was crazy, but he's never pulled anything like this. I saw it, I was looking out the window when it happened."

This remark seemed odd to Myers, and he looked at the man. Edgar was in his forties, nearly bald, and was dressed in slacks and a sweater and was wearing leather slippers.

"His name is Buzzy," Hilda announced and made a face. "It's Edgar's dog. I can't have an animal in the house myself, but Edgar bought this dog recently and promised to keep him outside at all times."

"He sleeps in the garage," Edgar said. "He begs to come in the house, but we can't allow it, you know. I think his frustration must have gotten the better of him tonight." He chuckled. "But sit down, sit down, if you can find a place with this clutter. Hilda, dear, move some of those things off the couch so Mr. and Mrs. Myers can sit down."

Hilda cleared the couch of packages, wrapping paper, scissors, a box of ribbons, and some loose bows. She put everything on the floor.

Myers noticed Edgar staring at him again, not smiling now. Paula said, "Myers, there's something in your hair, honey."

Myers put a hand up to the back of his head and found a dried leaf and a twig.

"That dog," Edgar said and chuckled again. "We were just having a hot drink and wrapping some last-minute gifts. Will you join us in a cup of holiday cheer? What would you like?"

"Anything is fine," Paula said.

"Anything," Myers said. "We shouldn't have interrupted."

"Nonsense," Edgar said. "We've been . . . very curious about the Myers. You'll have a hot drink, sir?"

“That's fine," Myers said.

"Mrs. Myers?" Edgar said.

Paula nodded.

"Two hot drinks coming up," Edgar said. "Dear, I think we're ready too, aren't we?" he said to his wife. "This is certainly an occasion." He took her cup and went out to the kitchen.

Myers heard the cupboard door bang and a muffled word that sounded like 
a curse. He blinked. He looked at Hilda Morgan who was settling herself into a chair at the end of the couch.

"Sit down over here, you two," Hilda said. She patted the arm of the couch. "Over here, by the fire. We'll have Mr. Morgan build it up again when he returns." They sat. Hilda clasped her hands in her lap and leaned forward slightly as if examining his face.

The living room was as he remembered it, except that on the wall behind Hilda's chair he saw three small framed prints. In one print a man in a vest and frock coat was tipping his hat to two ladies who held parasols. There were trees in the background, and a broad concourse with horses and carriages.

"How was Germany?" Paula said. She sat on the edge of the cushion and held her purse on her knees.

"We loved Germany," Edgar said, coming in from the kitchen with a small tray and four large cups.

Myers recognized the cups. He and Paula had used them when they lived here.

"Have you been to Germany, Mrs. Myers?" Edgar asked.

"We want to go," Paula said. "Don't we, Myers? Maybe next year, next summer. Or else the year after. As soon as we can afford it. Maybe as soon as Myers sells something. Myers writes."

"I should think a trip to Europe would be very beneficial to a writer," Edgar said. He put the cups into coasters. "Please help yourselves." He sat down in a chair across from his wife and gazed at Myers. "You said in your letter you were taking off work to write."

"That's true," Myers said and sipped his drink.

"He writes something almost every day," Paula said.

"Is that a fact?" Edgar said. "That's impressive. What did you write today, if I may ask?"

"Nothing," Myers said.

"It's the holidays," Paula said.

"You must be proud of him, Mrs. Myers," Hilda said.

"I am," Paula said.

"I'm happy for you," Hilda said.

"I heard something the other day that might interest you," Edgar said. He took out some tobacco and began to fill a pipe. Myers lighted a cigarette and looked around for an ashtray. He dropped the match behind the couch. "It's a horrible story really, but maybe you could use it, Mr. Myers." Edgar struck a flame and drew on the pipe. "Grist for the mill, you know, and all that," Edgar said and laughed and shook the match. "This fellow was about my age or so. He was a colleague for a couple of years. We knew each other a little, and we had good friends in common. Then he moved out, accepted a position at the university down the way. Well, you know how those things go sometimes, he began having an affair with one of his students."

Hilda made a disapproving noise with her tongue. She reached down for a small package that was wrapped in green paper and began to affix a red bow to the paper.

"According to all accounts, it was a torrid affair that lasted for some months," 
Edgar continued. "Right up until a short time ago, in fact. A week ago, to be exact. On that day, it was in the evening, he announced to his wife, they'd been married for twenty years, he announced to his wife that he wanted a divorce. You can imagine how his wife took it, coming out the blue like that, so to speak. There was quite a row. The whole family got into it. She ordered him out of the house then and there. But just as he was leaving, his son, mark this, his son, who is seventeen and in high school, his son threw a can of tomato soup at his father and hit him in the forehead. It caused a concussion that sent the father to the hospital. His condition is quite serious." He drew on his pipe and gazed at Myers.

"I've never heard such a story," Hilda said. "Edgar, that's disgusting."

"Horrible," Paula said.

Myers grinned.

"Now there's a story for you, Mr. Myers," Edgar said, catching the grin and narrowing his eyes. "Think of the story if you could get inside that man's head."

"Or her head," Hilda said. "The wife's. Think of her story. To be betrayed in such fashion after twenty years. Think how she must feel."

"But imagine what that poor boy must be going through," Paula said. "Imagine, having almost killed his father."

"Yes, that's all true," Edgar said. "But here's something I don't think any of you has thought about. Think about this for a moment. Mr. Myers, are you listening? Tell me what you think of this. Put yourself in the shoes of that eighteen year old coed who fell in love with a married man. Think about her for a moment, and then you see the possibilities for your story." He nodded and leaned back in the chair with a satisfied expression.

"I'm afraid I don't have any sympathy for her," Hilda said. "I can imagine the sort she is. We all know what she's like. That kind preys on older men. I don't have any sympathy for him either, the man, the chaser, no I don't. No, I'm afraid my sympathies in this case are entirely with the wife and son."

"It would take a Tolstoy to tell it and tell it right," Edgar said. "No less than a Tolstoy. Mr. Myers, the water is still hot."

"Time to go," Myers said. He stood up and threw his cigarette into the fire.

"Stay," Hilda said. "We haven't got acquainted yet. You don't know how we have ... speculated about you. Now that we're together at last, stay a little while. It's such a pleasant surprise."

"We appreciated the card and your note," Paula said.

"The card?" Hilda said.

Myers sat down again.

"We decided not to mail any cards this year," Paula said. "I didn't get around to it when I should have, and it seemed futile to do it at the last minute."

"You'll have another one, Mrs. Myers?" Edgar said, standing in front of her now with his hand on the cup. "You'll set an example for your husband?"

"It was good," Paula said. "It warms you."

"Right," Edgar said. "It warms you, that's right. Dear, did you hear Mrs. Myers? It warms you. That's very good."

"Mr. Myers?" he said and waited. "You'll join us?"

"All right," Myers said and let him take the cup. 
The dog began to whine and scratch at the door.

"That dog. I don't know what's gotten into that dog tonight," Edgar said. He went to the kitchen and this time Myers distinctly heard him curse as he slammed the kettle onto a burner.

Hilda began to hum. She picked up a package half-wrapped, cut a piece of tape, and began sealing the paper.

Myers and Paula looked at each other. Myers lighted a cigarette. He dropped the match in his coaster. He looked at his watch.

In a moment, Hilda raised her head. "I believe I hear singing," she said. She listened. She rose from her chair and went to the front window. "It is singing. It's carolers. Carolers. Edgarl" she called. Myers and Paula went to the window. "I haven't seen carolers in years," Hilda said.

"What is it?" Edgar said. He had the tray and cups. "What is it? What's wrong?"

"Nothing's wrong, dear. It's carolers. There they are over there, across the street," Hilda said.

"Mrs. Myers," Edgar said, extending the tray. "Mr. Myers. Dear."

"Thank you," Paula said.

"Muchas gracias," Myers said.

Edgar put the tray down and came back to the window with his cup. There were nearly a dozen young people gathered on the walk in front of the house across the street. Boys and girls with an older, taller boy who wore a muffler and a topcoat. Myers could see the faces at the window across the way-the Ardreysand when the carolers had finished, Jack Ardrey came to the door and gave something to the older boy. The group moved on down the walk, flashlights bobbing, and stopped in front of another house.

"They won't come here," Hilda said after a time.

"What? Why won't they come here?" Edgar said and turned to his wife. "What a Goddamned silly thing to say! Why won't they come here?"

"No, I just know they won't," Hilda said.

"And I say they will," Edgar said. In a minute, still watching, he said, "Mrs. Myers, are those carolers going to come here or not? What do you think? Will they return to bless this house? We'll leave it up to you."

Paula pressed closer to the window, but the carolers were far down the street now. Paula didn't answer. She continued looking out the window.

"Well, now that all the excitement is over," Edgar said, and went over to his chair. He sat down, frowned, and began to fill his pipe.

Myers and Paula went back to the couch. Hilda moved away from the window at last. She sat down. She smiled and gazed into her cup. Then she put the cup down and began to weep.

Edgar gave his handkerchief to his wife. He looked at Myers. Presently he began to drum on the arm of his chair. Myers moved his feet. Paula looked into her purse for a cigarette. "See what you've caused," Edgar said as he stared at something on the carpet near Myers' shoes.

Myers couldn't believe he had heard him say this. Paula squeezed his thigh, and Myers gathered himself to stand.

"Edgar, get them another drink," Hilda said as she dabbed her eyes. She used 
the handkerchief on her nose. "I want them to hear about Mrs. Attenborough. Mr. Myers writes. I think he might appreciate this. We'll wait until you come back before we begin the story."

Edgar collected the cups without saying anything. He carried them into the kitchen. Myers heard dishes clatter, cupboard doors bang. Hilda seemed oblivious. She looked at Myers and smiled faintly.

"We have to go," Myers said. "We have to. Paula, get your coat."

"No, no, we insist, Mr. Myers," Hilda said. "We want you to hear about Mrs. Attenborough, poor Mrs. Attenborough. You might appreciate this story, too, Mrs. Myers. This is your chance to see how his mind goes to work on raw material."

Edgar came back and passed out the hot drinks. He sat down quickly.

"Tell them about Mrs. Attenborough, dear," Hilda said to her husband.

"That dog almost tore my leg off," Myers said, and was at once surprised at his words. He put his cup down.

"Oh, come, it wasn't that bad," Edgar said. "I saw it."

"You know writers," Hilda said to Paula. "They like to exaggerate."

"The power of the pen and all that," Edgar said.

"That's it," Hilda said. "Bend your pen into a plowshare, Mr. Myers."

"We'll let Mrs. Morgan tell the story of Mrs. Attenborough," Edgar said, ignoring Myers who stood up at that moment. "Mrs. Morgan was intimately connected with the affair. I've already told you of the fellow who was knocked for a loop with a can of soup." He chuckled. "We'll let Mrs. Morgan tell this one."

"You tell it, dear. And Mr. Myers, you listen closely," Hilda said.

"We have to go," Myers said. "Paula, let's go."

"Talk about honesty," Hilda said.

"Let's talk about it," Myers said. Then he said, "Paula, are you coming?"

"I want you to hear this story," Edgar said, raising his voice. "You will insult Mrs. Morgan, you will insult us both, if you don't listen to this story." He clenched his pipe.

"Myers, please," Paula said anxiously. "I want to hear it, honest. Then we'll go. Myers? Please, honey, sit down for another minute."

Myers looked at her. She moved her fingers, as if signaling him. He hesitated, and then he sat next to her.

Hilda began. "One afternoon in Munich, Edgar and I went to the Dortmunder Museum. There was a Bauhaus exhibit that fall and Edgar said, the heck with it, let's take a day off-he was doing his research you see-the heck with it, let's take a day off. We caught a tram and rode across Munich to the museum. We spent several hours viewing the exhibit and revisiting some of the galleries to pay homage to a few of our favorites amongst the old masters. Just as we were to leave, I stepped into the ladies' room. I left my purse. In the purse was Edgar's monthly check from home that had come the day before, and a hundred and twenty dollars cash that I was going to deposit along with the check. I also had my identification cards in the purse. I did not miss it until we arrived home. Edgar immediately telephoned the museum authorities, but while he was talking I saw a taxi out front. A well-dressed woman with white hair got out. She was a stout woman and she was carrying two purses. I called for Edgar and went to the 
door. The woman introduced herself as Mrs. Attenborough, gave me my purse, and explained that she too had visited the museum that afternoon and while in the ladies' room had noticed a purse in the trash can. She of course opened the purse in an effort to trace the owner. There were the identification cards and such giving our local address. She immediately left the museum and took a taxi in order to deliver the purse herself. Edgar's check was there, but the money, the hundred and twenty dollars, was gone. Nevertheless, I was grateful the other things were intact. It was nearly four o'clock and we asked her to stay for tea. She sat down and after a little while began to tell us about herself. She had been born and reared in Australia, had married young, had three children, all sons, been widowed, and still lived in Australia with two of her sons. They raised sheep and had more than 20,000 acres of land for the sheep to run in, and many drovers and shearers and such who worked for them at certain times of the year. When she came to our home in Munich, she was then on her way home to Australia from England where she had been to visit her youngest son who was a barrister. She was returning to Australia when we met her," Hilda went on. "She was seeing some of the world in the process. She had many places yet to visit on her itinerary."

"Come to the point, dear," Edgar said.

"Yes. Here is what happened then. Mr. Myers, I'll go right to the climax, as you writers say. Suddenly, after we had had a very pleasant conversation for an hour, after she had told about herself and her adventurous life Down Under, she stood up to go. As she started to pass me her cup, her mouth flew open, the cup dropped, and she fell across our couch and died. Died, right in our living room. It was the most shocking moment in our lives."

Edgar nodded solemnly.

"God," Paula said.

"Fate sent her to die on the couch in our living room in Germany," Hilda said.

This struck Myers as funny and he began to laugh. "Fate--sent--her--to die--in-your--living--room?" he said between gasps.

"Is that funny, sir?" Edgar said. "Do you find that amusing?"

Myers nodded. He kept laughing. He wiped his eyes on his shirt sleeve. "I'm really sorry," he said. "I can't help it. That line, 'Fate sent her to die in our living room in Germany.' I'm sorry. Then what happened?" he managed to say. "I'd like to know how this ended."

"Mr. Myers, we didn't know what to do," Hilda said. "The shock was terrible. Edgar felt her pulse, but there was no sign of life. And she had begun to change color. Her face and hands were turning gray. Edgar went to the phone to call someone. Then he said, 'Open her purse, see if you can find where she's staying.' All the time averting my eyes from the poor thing there on the couch, I took up her purse. Imagine my complete surprise and bewilderment, my utter bewilderment, when the first thing I saw inside was my hundred and twenty dollars, still fastened with the paper clip. I was never so astonished."

"And disappointed," Edgar said. "Don't forget that. It was a keen disappointment."

Myers giggled. 
"If you were a real writer, as you say you are, Mr. Myers, you wouldn't laugh," Edgar said as he got to his feet. "You wouldn't dare laugh! You'd try to understand. You'd plumb the depths of that poor soul's heart and try to understand. But you're no writer, sir!"

Myers kept laughing.

Edgar slammed the coffee table and the empty cups rattled in the coasters. "The real story lies right here, in this house, this very living room, and it's time it was told! The real story is here, Mr. Myers," Edgar said. He walked up and down over the shiny wrapping paper which had unrolled and now lay spread out across the carpet. He stopped to glare at Myers, who was by now holding his forehead and shaking with laughter. "Consider this for a possibility, Mr. Myers! Consider. A friend, let's call him Mr. X, is friends with, with Mr. and Mrs. Y, as well as Mr. and Mrs. Z. Mrs. and Mrs. $\mathrm{Y}$ and Mr. and Mrs. Z do not know each other, unfortunately. I say unfortunately, because if they had known each other this story would not exist because it would never have taken place. Now Mr. X learns that Mr. and Mrs. Y are going away to Germany for a year and need someone to occupy their house during the time they are gone. Mr. and Mrs. $\mathrm{Z}$ are looking for suitable accommodations, and Mr. $\mathrm{X}$ tells them he knows of just the place. But before Mr. X can put Mr. and Mrs. $\mathrm{Z}$ in touch with $\mathrm{Mr}$. and Mrs. Y, the Y's have to leave sooner than expected. Mr. X, being a friend, is left to rent the house at his discretion to anyone, including Mr. and Mrs. Y, I mean Z. Now Mr. and Mrs. ...-Z move into the house and bring a cat with them that Mr. and Mrs. Y hear about later in a letter from Mr. X. Mr. and Mrs. Z bring a cat into the house even though the terms of the lease have expressly forbidden cats or other animals in the house because of Mrs. Y's asthma. The real story, Mr. Myers, lies in the situation I've just described. Mr. and Mrs. Z, I mean Mr. and Mrs. Y's moving into the Z's house, invading the Z's house, if the truth is to be told. Sleeping in the Z's bed is one thing, but unlocking the Z's private closet and using their linen, vandalizing the things found there, that was against the spirit and letter of the lease. And this same couple, the Z's, opened boxes of kitchen utensils marked Don't Open. And they broke dishes when it was spelled out, spelled out in that same lease, they were not to use the owners', that is the Z's personal, I emphasize personal, possessions." His lips were white. He continued to walk up and down on the paper, stopping every now and then to look at Myers and emit little puffing noises from his lips.

"And the bathroom things, dear, don't forget the bathroom things," Hilda said. "It's bad enough using the X's blankets and sheets, but when they also get into their bathroom things and go through the little private things stored in the attic, a line has to be drawn."

"That's the real story, Mr. Myers," Edgar said. He tried to fill his pipe. His hands trembled and tobacco spilled onto the carpet. "That's the real story that's waiting to be written."

"And it doesn't need Tolstoy to tell it," Hilda put in.

"It doesn't need Tolstoy," Edgar said.

Myers laughed. He and Paula got up from the couch at the same time and moved toward the door. "Good night," Myers said merrily. 
Edgar was behind him. "If you were a real writer, sir, you'd put that story into words, and not pussyfoot around with it either."

Myers laughed again. He touched the doorknob. "One other thing," Edgar said. "I didn't intend to bring this up, but in light of your behavior here tonight, I wanted to tell you that I'm missing my two-volume set of Jazz at the Philharmonic. Those records are of great sentimental value. I bought them in 1955. And now I insist you tell me what happened to them."

"In all fairness, Edgar," Hilda said as she helped Paula with her coat, "after you took inventory of the records, you admitted you couldn't recall the last time you had seen those records."

"I'm sure of it now, though," Edgar said. "I'm positive I saw those records just before we left, and now, now I'd like this writer to tell me exactly what he knows of their whereabouts. Mr. Myers?"

But Myers was already out the door and, taking Paula by the hand, he hurried her down the walk to the car. They surprised Buzzy on the walk who yelped at them and then jumped to the side.

"I insist on knowing," Edgar called after them. "The nerve of some peoplel"

Myers got Paula into the car and then started the engine. He looked again at the couple on the porch. Hilda waved, and then she and Edgar went back inside and shut the door. They looked out at the car from behind the curtain.

Myers pulled away from the curb. "Those people are crazy," Paula said. This remark, too, struck Myers as funny. He patted her hand.

"They were scary," she said. In a minute, she leaned her head against his shoulder and said, "Honey, I'm going to fall asleep."

He didn't answer. Her voice seemed to come to him from a great distance. He kept driving. Snow rushed at the windshield. He was silent and watched the road. He was at the very end of a story. 